\title{
Association of snps of aif-1 gene with susceptibility to oral cancer in chinese population
}

\author{
Liqiong ZHANG ${ }^{1}$, Shaolin $\mathrm{DENG}^{1 *}$ (1)
}

\begin{abstract}
To investigate the association between allograft inflammatory factor-1 (AIF-1) gene polymorphism and susceptibility to oral cancer in Chinese population. A case-control study was conducted to collect 400 cases of newly diagnosed oral cancer patients diagnosed by pathology from January 2015 to June 2019 and 400 cases of physical examination in the same period. Single nucleotide polymorphisms (SNPs) of the AIF-1 gene were detected using TaqMan probe technology. Unconditional logistic regression analysis was used to calculate the odd ratios (OR) and 95\% confidence interval (CI) of the association between AIF-1 gene polymorphism and oral cancer susceptibility. GG genotypes reduced the risk of oral cancer in co-dominant models $(O R=0.499,95 \% C I: 0.328-0.760, P=0.001)$ and recessive models $(O R=0.496,95 \% C I: 0.342-0.729, P<0.001)$. There was no significant difference between the case group and the control group in the dominant model genotype $(O R=0.836,95 \%$ CI: $0.623 \sim 1.121, P=0.836$ ). Conclusion AIF-1 gene rs2857595 gene SNPs can reduce the risk of oral cancer.
\end{abstract}

Keywords: AIF-1 gene; oral cancer; case-control study.

Practical Application: In the future, the AFS-1 gene rs 2857595 locus GG genotype should be considered in the development of precise prevention strategies and measures for oral cancer.

\section{Introduction}

Head and neck cancer can occur in the paranasal sinuses, sinuses, nasopharynx, oropharynx, mouth, pharynx, and throat. Head and neck cancer affects more than 500,000 people worldwide each year, and the incidence of oral cancer is increasing in the young population (Anderson et al., 2019; Bachok et al., 2018; Balaguer et al., 2020; Funahara et al., 2017). The occurrence of head and neck cancer has a serious impact on the quality of life of patients, such as communication, breathing and difficulty swallowing (Matar \& Haddad, 2011; Lin et al., 2012). The treatment of head and neck cancer often causes problems such as pain, diet and communication, which seriously affects the mental health of patients (Devins et al., 2013; Sreekumar, 2019).

Studies (Alkhubaizi et al., 2018; Kadashetti et al., 2017; Wei et al., 2014) have shown that smoking, drinking and other factors are the main risk factors for oral cancer, and the proportion of patients with oral cancer in non-smokers and non-drinkers is about $15 \%$ to $20 \%$ (Laco et al., 2011). It is suggested that genetic factors may play a non-negligible role in it. The results of a genome-wide association study (GWAS) by Wei et al. (2014) suggest that single nucleotide polymorphisms (SNPs) of the rs2857595 locus of the AIF-1 gene are associated with the susceptibility of laryngeal squamous cell carcinoma (LSCC) in Chinese population. However, the subjects were all male and did not include females.

Obesity is a risk factor for many tumors (Renehan et al., 2008; Barnes et al., 2016; Zhao et al., 2017), it have found that obesity can reduce the risk of head and neck cancer (such as oral cancer) (Maasland et al., 2015; Radoï et al., 2013). AIF-1 gene is associated with body mass index (BMI) (Rouskas et al., 2012; Thorleifsson et al., 2009). Therefore, effective head and neck cancer markers have been found to play a key role in understanding tumor causes, patient outcomes, and in-depth research. This study used a case-control study to explore the association between AIF-1 gene SNPs and susceptibility to oral cancer, and to provide a scientific basis for the development of accurate prevention strategies and measures for oral cancer.

\section{Materials and methods}

\subsection{Methods}

A case-control study was conducted to collect 400 cases (case groups) of newly diagnosed oral cancer patients diagnosed by pathology from January 2015 to June 2019 and 400 (control group) of the hospital for the same period. The investigators from the case group and the control group conducted an epidemiological questionnaire survey to collect the general demographic characteristics of the subjects and the exposure history of smoking and drinking. At the same time, $5 \mathrm{~mL}$ of peripheral blood of each subject was collected for DNA extraction and genotyping. This study was approved by the our hospital. All participants participated in the written informed consent form.

\subsection{DNA extraction}

DNA extraction mainly concludes as follows: (1) The whole blood sample was transferred to a $10 \mathrm{~mL}$ centrifuge tube, and 
then the red blood cell lysate was added, and the mixture was inverted and mixed for about 200 minutes, and then allowed to stand for 30 minutes. (2) Centrifuge at $4000 \mathrm{r} \times 6 \mathrm{~min}$, discard the supernatant, resuspend the pellet by adding $1 \mathrm{~mL}$ of phosphate buffered saline (PBS), mix by pipetting and transfer to a $1.5 \mathrm{~mL}$ EP tube. (3) Centrifuge again at $5000 \mathrm{r} \times 6 \mathrm{~min}$, discard the supernatant, add $0.1 \mathrm{~mL}$ PBS and $0.7 \mathrm{~mL}$ DNAzol, mix by pipetting. (4) Add $0.5 \mathrm{~mL}$ of $100 \%$ ethanol, mix by inversion, centrifuge at $12000 \mathrm{r} \times 5 \mathrm{~min}$, and discard the supernatant. (5) Add $1 \mathrm{~mL}$ of $75 \%$ ethanol, shake well, centrifuge at $12000 \mathrm{r} \times 2 \mathrm{~min}$, and discard the supernatant. (6) When drying naturally to the micro-dry, add $400 \mu \mathrm{L}$ of double distilled water. (7) After taking $1 \mu \mathrm{L}$ of the measured DNA content, four tubes were dispensed and stored in a refrigerator at $-20^{\circ} \mathrm{C}$.

\subsection{Genotyping}

Genotyping assays were performed using TaqMan probe technology. The probe and primer sequences are shown in Table 1. The specific experimental procedures are as follows: (1) Pre-denaturation at $95^{\circ} \mathrm{C}$ for $10 \mathrm{~min}$. (2) Following denaturation at $95^{\circ} \mathrm{C}$ for $5 \mathrm{~s}$, then annealing at $60^{\circ} \mathrm{C}$ for $30 \mathrm{~s}$, this step is carried out for 40 cycles. (3) Finally placed in an environment of $4{ }^{\circ} \mathrm{C}$. The polymerase chain reaction (PCR) total reaction system is $5 \mu \mathrm{L}: 1 \mu \mathrm{L}$ DNA template, $2 \times$ TaqMan Universal Master Mix $2.5 \mu \mathrm{L}$, upstream and downstream primers each $0.225 \mu \mathrm{L}, \mathrm{P} 1 /$ P2 each $0.095 \mathrm{Ml}$, ddH2O 0.86 $\mathrm{L}$. All assays were performed in 96-well plates with 8 replicates and 8 blanks in each plate and $5 \%$ of the samples were randomly selected for repeated determination. The success rate of all the sites was over $99.0 \%$, and the agreement rate was $100 \%$.

\subsection{Statistical analysis}

The chi-square analysis was used for the count data and the t-test was used for the measurement data. Unconditional logistic regression model was used to analyze the association of ANP-1 gene rs2857595 SNPs with oral cancer and the odd ratios (OR) and 95\% CI were calculated. All statistical analyses were performed using the Stata 23.0 software package with a test level of $\alpha=0.05$. A two-sided test $P<0.05$ considered the difference between the case group and the control group to be statistically significant.

\section{Results}

\subsection{General characteristics of the research objects}

A total of 400 Chinese patients with oral cancer were enrolled in the study, including 365 patients with squamous cell carcinoma, 35 patients with adenocarcinoma and other pathological types, and an average age of $(55.74 \pm 12.19)$ years. There were 400 patients in the control group with an average age of ( $54.06 \pm 13.03)$ years. In the case group, 216 cases were 56 years old and above, accounting for $54.0 \%$; in the control group, 177 cases were 56 years old and above, accounting for $44.3 \%$. There were 259 males in the case group, accounting for $64.8 \%$; 262 males in the control group, accounting for $65.5 \%$. The case group was full-time 281 cases, accounting for $70.3 \%$; the control group was full-time 316 cases, accounting for $79.0 \%$. The marital status of the case group was 345 cases of marriage, accounting for $86.3 \%$; the marital status of the control group was 352 cases of marriage, accounting for $88.0 \%$. The education level of the case group was 238 cases of primary school and below, accounting for $59.5 \%$; the control group had 68 cases of primary school and below, accounting for $17.0 \%$. The case group lived in 203 cities, accounting for 50.8\%; the control group lived in 130 cities, accounting for $32.5 \%$. There were 253 cases of smoking in the case group, accounting for $63.3 \%$; 139 cases of smoking in the control group, accounting for $34.8 \%$. In the case group, 168 cases were alcoholic, accounting for $42.0 \%$; in the control group, 95 cases were drinking, accounting for $23.8 \%$. In the case group, 100 cases of BMI were 24 or above, accounting for $25.0 \%$; in the control group, 194 cases of BMI were 24 or above, accounting for $48.5 \%$. Univariate analysis showed that compared with the control group, the differences in age, occupation, education level, place of residence, smoking, drinking, BMI and other factors were statistically significant $(\mathrm{P}<0.05)$. The results of the analysis are shown in Table 2.

\subsection{Association of rs 2857595 with susceptibility to oral cancer}

The analysis showed that the distribution of genotype frequencies of rs 2857595 was statistically significant between the case group and the control group (chi-square value $=13.24$, $P=0.001)$. Moreover, this locus conforms to the law of genetic balance of hardy-weinberg $(\mathrm{H}-\mathrm{W})$ (chi-square value $=2.051$, $P=0.152$ ). Logistic regression analysis suggested that GG genotypes can reduce the risk of oral cancer in the codominant model $(O R=0.499,95 \% C I: 0.328-0.760, P=0.001)$ and the recessive model $(O R=0.496,95 \% C I$ : $0.342-0.729, P<0.001)$, and the results are shown in Table 3. There was no significant difference between the case group and the control group in the dominant model genotype $(O R=0.836,95 \% C I: 0.623 \sim 1.121$, $P=0.836)$.

\section{Discussion}

Smoking is considered to be an important risk factor for oral cancer (Alkhubaizi et al., 2018; Rogers et al., 2019;

Table 1. Probe and primer sequences in PCR.

\begin{tabular}{ccc}
\hline Number & Primer/probe & Base order $\left(5^{\prime} \ldots \ldots \ldots \ldots \ldots \ldots . . . . . . . .3\right.$ \\
rs2857595-P1 & Probe & FAM-AGAAGTCACCCAATCT-MGB \\
rs2857595-P2 & Probe & HEX-AGTCACTCAATCTC-MGB \\
rs2857595-F & Primer & GGGAGCCATTCATTAGTTGAAAAATAT \\
rs2857595-R & Primer & AAAGTCCACAATCCAGCACAGG \\
\hline
\end{tabular}


Table 2. Comparison of general characteristics between the two groups of respondents.

\begin{tabular}{|c|c|c|c|c|c|c|}
\hline \multirow{2}{*}{ Variables } & \multicolumn{2}{|c|}{ Case group } & \multicolumn{2}{|c|}{ Control group } & \multirow{2}{*}{$\chi^{2}$ or $t$} & \multirow{2}{*}{ P (Probability) } \\
\hline & No. & col \% & No. & $\operatorname{col} \%$ & & \\
\hline \multicolumn{7}{|l|}{ Age } \\
\hline $56 \sim$ & 216 & 54.0 & 177 & 44.3 & & \\
\hline \multicolumn{7}{|l|}{ Gender } \\
\hline Male & 259 & 64.8 & 262 & 65.5 & & \\
\hline \multicolumn{7}{|l|}{ Occupation } \\
\hline Part time & 119 & 29.8 & 84 & 21.0 & 8,086 & 0.004 \\
\hline Full time & 281 & 70.3 & 316 & 79.0 & & \\
\hline \multicolumn{7}{|l|}{ Education } \\
\hline Elementary school and below & 238 & 59.5 & 68 & 17.0 & 153.807 & $<0.001$ \\
\hline Junior school & 106 & 26.5 & 202 & 50.5 & & \\
\hline High school and above & 56 & 14.0 & 130 & 32.5 & & \\
\hline \multicolumn{7}{|l|}{ Place of residence } \\
\hline Rural & 197 & 49.3 & 279 & 69.8 & 27.414 & $<0.001$ \\
\hline City & 203 & 50.8 & 130 & 32.5 & & \\
\hline \multicolumn{7}{|l|}{ Smoking } \\
\hline None & 147 & 36.8 & 262 & 65.5 & 65.006 & $<0.001$ \\
\hline$<18.5$ & 58 & 14.5 & 17 & 4.3 & 58.985 & $<0.001$ \\
\hline $18.5-24$ & 242 & 60.5 & 189 & 47.3 & & \\
\hline$\geq 24$ & 100 & 25.0 & 194 & 48.5 & & \\
\hline
\end{tabular}

Table 3. The unconditional Logistic regression of rs2857595 on oral cancer.

\begin{tabular}{|c|c|c|c|c|c|c|}
\hline \multirow{2}{*}{ Type } & \multicolumn{2}{|c|}{ Case group } & \multicolumn{2}{|c|}{ Control group } & \multirow{2}{*}{ Odds Ratio (95\% CI) } & \multirow{2}{*}{ P (Probability $)$} \\
\hline & No. & $\mathrm{col} \%$ & No. & $\operatorname{col} \%$ & & \\
\hline \multicolumn{7}{|c|}{ Co-dominant genetic model } \\
\hline AG(Genotype AG) & 207 & 51.8 & 184 & 46.0 & $0.999(0.732-1.363)$ & 0.996 \\
\hline GG(Genotype GG) & 50 & 12.5 & 89 & 22.3 & $0.499(0.328-0.760)$ & 0.001 \\
\hline AA & 143 & 35.8 & 127 & 31.8 & 1.0 & \\
\hline $\mathrm{AG}+\mathrm{GG}$ & 257 & 64.3 & 273 & 68.3 & $0.836(0.623-1.121)$ & 0.836 \\
\hline \multicolumn{7}{|l|}{ Recessive genetic model } \\
\hline $\mathrm{AA}+\mathrm{AG}$ & 350 & 87.5 & 311 & 77.8 & 1.0 & \\
\hline
\end{tabular}


Yoon et al., 2019). Polycyclic aromatic hydrocarbons, heterocyclic amines and nitrosamines in cigarettes are well-defined chemical carcinogens. At present, most chemical carcinogens are known to require biotransformation activation or detoxification in vivo. The metabolic enzymes involved in this process are divided into two categories, namely, phase I metabolic enzymes and phase II metabolic enzymes. Phase I metabolic enzymes are metabolically activated enzymes, and many procarcinogens are metabolically activated to become the ultimate carcinogen. The phase II metabolic enzyme is a metabolic detoxifying enzyme that converts carcinogens or their toxic metabolites into substances that are harmless to the human body and excreted from the body. Whether a carcinogen causes cancer of a target cell depends to a large extent on the activity of the two enzymes and their equilibrium relationship.

Most of the genes of metabolic enzymes are polymorphic, and the polymorphism of some genes can cause changes in enzyme activity, leading to differences in individual tumor susceptibility. The development of oral cancer is a multi-step process in which many causes and host susceptibility interact. Most environmental carcinogens require carcinogenesis after metabolic activation in the body. Many of the former carcinogens in tobacco also need to be activated and detoxified by in vivo phase I and phase II metabolic enzymes. CYP1A1 is one of the important phase I metabolic enzymes, which can catalyze the phase I oxidation of foreign compounds such as acetaldehyde into the body, and convert the inactive procarcinogen activation into an electrophilic compound (Divya et al., 2018; Shahid et al., 2019). The electrophilic compound can attack biological macromolecules in cells and form adducts with DNA or proteins. Eventually it causes changes in oncogenes and tumor suppressor genes, leading to cancer.

Oral cancer is a general term for malignant tumors that occur in the mouth. In recent years, the incidence of oral cancer has been increasing (Hou et al., 2015). Previous studies have found that AIF-1 gene rs2857595 locus polymorphism can reduce the risk of laryngeal squamous cell carcinoma (Wei et al., 2014), which is basically consistent with the results of this study. AIF-1 is a gene located in the genomic region of human leukocyte antigen class III on chromosome 6. Although the mechanism of rs2857595 gene polymorphism and susceptibility to oral cancer has not been reported, there is a linkage disequilibrium between rs2857595 locus and multiple inflammatory genes (Wei et al., 2014). In addition, a recent animal study found that AIF-1 protein as a biomarker for intestinal mucosal barrier repair can promote intestinal mucosal damage healing by reducing the intestinal mucosal inflammatory response and increasing the differentiation of intestinal mucosal cells (Roman et al., 2017). Although this study only explored the relationship between AIF-1 and intestinal mucosal injury repair, the results suggest that the relationship between AIF-1 gene and oral cancer may be related to the healing of oral mucosal injury, but the specific mechanism remains to be further studied.

Obesity is a risk factor for many malignant tumors, which could reduce the risk of head and neck cancer (Maasland et al., 2015; Radoï et al., 2013). Many carcinogens (such as polycyclic aromatic hydrocarbons) are lipophilic and can accumulate in adipose tissue, so the body fat content may affect the distribution of carcinogens in the human body, which may lead to tumors (Gaudet et al., 2010). 8-hydroxydeoxyguanosine (8-OHdG) is a marker of DNA oxidative damage (Mizoue et al., 2006). Previous studies have found a negative correlation between BMI levels and 8-OHdG levels in the body. Low body weight may increase the oxidative damage of DNA by smoking and other factors (Nigam et al., 2019; Tang et al., 2018a, b; Chang et al., 2016), thereby promoting tumorigenesis.

Because of the case-control study used in this study, there may be some selection bias and recall bias. However, the investigators in this study have undergone unified training, focusing on quality control, and the selected participants are new cases, which minimizes selection bias and recall bias. Therefore, there is still a need to further expand the sample size of the multicenter study and conduct a prospective cohort study to validate the results of this study.

\section{Conclusion}

In summary, the AFS-1 gene rs2857595 locus GG genotype can reduce the risk of oral cancer. In the future, the AFS-1 gene rs2857595 locus GG genotype should be considered in the development of precise prevention strategies and measures for oral cancer.

\section{References}

Alkhubaizi, Q., Khalaf, M. E., Dashti, H., \& Sharma, P. N. (2018). Oral cancer screening among smokers and nonsmokers. Journal of International Society of Preventive \& Community Dentistry, 8(6), 553-559. http://dx.doi.org/10.4103/jispcd.JISPCD_197_18. PMid:30596048.

Anderson, C. M., Lee, C. M., Saunders, D. P., Curtis, A., Dunlap, N., Nangia, C., Lee, A. S., Gordon, S. M., Kovoor, P., Arevalo-Araujo, R., Bar-Ad, V., Peddada, A., Colvett, K., Miller, D., Jain, A. K., Wheeler, J., Blakaj, D., Bonomi, M., Agarwala, S. S., Garg, M., Worden, F., Holmlund, J., Brill, J. M., Downs, M., Sonis, S. T., Katz, S., \& Buatti, J. M. (2019). Phase IIb, Randomized, Double-Blind Trial of GC4419 Versus Placebo to Reduce Severe Oral Mucositis Due to Concurrent Radiotherapy and Cisplatin For Head and Neck Cancer. Journal of Clinical Oncology, 37(34), 3256-3265. http://dx.doi.org/10.1200/ JCO.19.01507. PMid:31618127.

Bachok, N., Biswal, B. M., Abdul Razak, N. H., Wan Zainoon, W. M. N., Mokhtar, K., Abdul Rahman, R., Abdullah, M. F., Mustafa, S. M. N., \& Noza, N. (2018). Preliminary Comparative Study of Oral7(R) Versus Salt-Soda Mouthwash on Oral Health Related Problems and Quality of Life among Head and Neck Cancer Patients Undergoing Radiotherapy. The Malaysian Journal of Medical Sciences : MJMS, 25(5), 79-87. http://dx.doi.org/10.21315/mjms2018.25.5.8. PMid:30914865.

Balaguer, M., Pommée, T., Farinas, J., Pinquier, J., Woisard, V., \& Speyer, R. (2020). Effects of oral and oropharyngeal cancer on speech intelligibility using acoustic analysis: Systematic review. Head \& neck, 42(1), 111-130. PMid:31571334.

Barnes, K. T., McDowell, B. D., Button, A., Smith, B. J., Lynch, C. F., \& Gupta, A. (2016). Obesity is associated with increased risk of invasive penile cancer. BMC Urology, 16(1), 42. http://dx.doi. org/10.1186/s12894-016-0161-7. PMid:27411982. 
Chang, H. S., Tang, J. Y., Yen, C. Y., Huang, H. W., Wu, C. Y., Chung, Y. A., Wang, H. R., Chen, I. S., Huang, M. Y., \& Chang, H. W. (2016). Antiproliferation of Cryptocarya concinna-derived cryptocaryone against oral cancer cells involving apoptosis, oxidative stress, and DNA damage. BMC Complementary and Alternative Medicine, 16(1), 94. http://dx.doi.org/10.1186/s12906016-1073-5. PMid:26955958.

Devins, G. M., Payne, A. Y., Lebel, S., Mah, K., Lee, R. N., Irish, J., Wong, J., \& Rodin, G. M. (2013). The burden of stress in head and neck cancer. Psycho-Oncology, 22(3), 668-676. http://dx.doi.org/10.1002/ pon.3050. PMid:22392570.

Divya, G. M., Zinia, N., Balagopal, P. G., Bipin, V. T., Elizabeth, I. M., Nebu, G. A., Shaji, T., \& Paul, S. (2018). Risk factors for post-operative complications in primary oral cancer surgery-a prospective study. Indian Journal of Surgical Oncology, 9(1), 28-34. http://dx.doi.org/10.1007/s13193-017-0668-8. PMid:29563731.

Funahara, M., Yanamoto, S., Ueda, M., Suzuki, T., Ota, Y., Nishimaki, F., Kurita, H., Yamakawa, N., Kirita, T., Okura, M., Mekaru, Y., Arakaki, K., \& Umeda, M. (2017). Prevention of surgical site infection after oral cancer surgery by topical tetracycline: Results of a multicenter randomized control trial. Medicine, 96(48), e8891. http://dx.doi.org/10.1097/MD.0000000000008891. PMid:29310375.

Gaudet, M. M., Olshan, A. F., Chuang, S.-C., Berthiller, J., Zhang, Z.-F., Lissowska, J., Zaridze, D., Winn, D. M., Wei, Q., Talamini, R., Szeszenia-Dabrowska, N., Sturgis, E. M., Schwartz, S. M., Rudnai, P., Eluf-Neto, J., Muscat, J., Morgenstern, H., Menezes, A., Matos, E., Bucur, A., Levi, F., Lazarus, P., La Vecchia, C., Koifman, S., Kelsey, K., Herrero, R., Hayes, R. B., Franceschi, S., Wunsch-Filho, V., Fernandez, L., Fabianova, E., Daudt, A. W., Dal Maso, L., Paula Curado, M., Chen, C., Castellsague, X., Benhamou, S., Boffetta, P., Brennan, P., \& Hashibe, M. (2010). Body mass index and risk of head and neck cancer in a pooled analysis of case-control studies in the International Head and Neck Cancer Epidemiology (INHANCE) Consortium. International Journal of Epidemiology, 39(4), 1091-1102. http://dx.doi.org/10.1093/ije/ dyp380. PMid:20123951.

Hou, J., Gu, Y., Hou, W., Wu, S., Lou, Y., Yang, W., Zhu, L., Hu, Y., Sun, M., \& Xue, H. (2015). P53 codon 72 polymorphism, human papillomavirus infection, and their interaction to oral carcinoma susceptibility. BMC Genetics, 16(1), 72. http://dx.doi.org/10.1186/ s12863-015-0235-7. PMid:26123760.

Kadashetti, V., Shivakumar, K. M., Chaudhary, M., Patil, S., Gawande, M., \& Hande, A. (2017). Influence of risk factors on patients suffering from potentially malignant disorders and oral cancer: A casecontrol study. Journal of Oral and Maxillofacial Pathology: JOMFP, 21(3), 455-456. http://dx.doi.org/10.4103/jomfp.JOMFP_236_14. PMid:29391728.

Laco, J., Vosmikova, H., Novakova, V., Celakovsky, P., Dolezalova, H., Tucek, L., Nekvindova, J., Vosmik, M., Cermakova, E., \& Ryska, A. (2011). The role of high-risk human papillomavirus infection in oral and oropharyngeal squamous cell carcinoma in non-smoking and non-drinking patients: a clinicopathological and molecular study of 46 cases. Virchows Archiv, 458(2), 179-187. http://dx.doi. org/10.1007/s00428-010-1037-y. PMid:21221634.

Lin, B. M., Starmer, H. M., \& Gourin, C. G. (2012). The relationship between depressive symptoms, quality of life, and swallowing function in head and neck cancer patients 1 year after definitive therapy. The Laryngoscope, 122(7), 1518-1525. http://dx.doi.org/10.1002/ lary.23312. PMid:22467530.
Maasland, D. H. E., Brandt, P. A., Kremer, B., \& Schouten, L. J. (2015). Body mass index and risk of subtypes of head-neck cancer: the Netherlands Cohort Study. Scientific Reports, 5(1), 17744. http:// dx.doi.org/10.1038/srep17744. PMid:26634678.

Matar, N., \& Haddad, A. (2011). New trends in the management of head and neck cancers. Le Journal medical libanais. The Lebanese medical journal, 59(4), 220-226. PMid:22746011.

Mizoue, T., Kasai, H., Kubo, T., \& Tokunaga, S. (2006). Leanness, smoking, and enhanced oxidative DNA damage. Cancer Epidemiology, Biomarkers \& Prevention, 15(3), 582-585. http://dx.doi.org/10.1158/10559965.EPI-05-0658. PMid:16537720.

Nigam, K., Yadav, S. K., Samadi, F. M., Bhatt, M. L., Gupta, S., \& Sanyal, S. (2019). Risk modulation of oral pre cancer and cancer with polymorphisms in XPD and XPG genes in North Indian population. Asian Pacific Journal of Cancer Prevention, 20(8), 2397-2403. http:// dx.doi.org/10.31557/APJCP.2019.20.8.2397. PMid:31450912.

Radoï, L., Paget-Bailly, S., Cyr, D., Papadopoulos, A., Guida, F., Tarnaud, C., Menvielle, G., Schmaus, A., Cenee, S., Carton, M., LapôtreLedoux, B., Delafosse, P., Stücker, I., \& Luce, D. (2013). Body mass index, body mass change, and risk of oral cavity cancer: results of a large population-based case-control study, the ICARE study. Cancer Causes \& Control, 24(7), 1437-1448. http://dx.doi.org/10.1007/ s10552-013-0223-z. PMid:23677332.

Renehan, A. G., Tyson, M., Egger, M., Heller, R. F., \& Zwahlen, M. (2008). Body-mass index and incidence of cancer: a systematic review and meta-analysis of prospective observational studies. Lancet, 371(9612), 569-578. http://dx.doi.org/10.1016/S01406736(08)60269-X. PMid:18280327.

Rogers, S. N., Swain, A., Carroll, C., Lowe, D. (2019). Incidence, timing, presentation, treatment, and outcomes of second primary head and neck squamous cell carcinoma after oral cancer. The British Journal of Oral \& Maxillofacial Surgery, 57(10), 1074-1080. PMID: 31611034.

Roman, I. D., Cano-Martinez, D., Lobo, M. V., Fernandez-Moreno, M. D., Hernandez-Breijo, B., Sacristan, S., Sanmartín-Salinas, P., Monserrat, J., Gisbert, J. P., \& Guijarro, L. G. (2017). Infliximab therapy reverses the increase of allograft inflammatory factor-1 in serum and colonic mucosa of rats with inflammatory bowel disease. Biomarkers, 22(2), 133-144. http://dx.doi.org/10.1080/13 54750X.2016.1252950. PMid:27781498.

Rouskas, K., Kouvatsi, A., Paletas, K., Papazoglou, D., Tsapas, A., Lobbens, S., Vatin, V., Durand, E., Labrune, Y., Delplanque, J., Meyre, D., \& Froguel, P. (2012). Common variants in FTO, MC4R, TMEM18, PRL, AIF1, and PCSK1 show evidence of association with adult obesity in the Greek population. Obesity (Silver Spring, Md.), 20(2), 389-395. http://dx.doi.org/10.1038/oby.2011.177. PMid:21720444.

Shahid, N., Iqbal, A., Siddiqui, A. J., Shoaib, M., \& Musharraf, S. G. (2019). Plasma metabolite profiling and chemometric analyses of tobacco snuff dippers and patients with oral cancer: Relationship between metabolic signatures. Head \& Neck, 41(2), 291-300. PMid:30548891.

Sreekumar, V. N. (2019). Global Scenario of Research in Oral Cancer. Journal of Maxillofacial and Oral Surgery, 18(3), 354-359. http:// dx.doi.org/10.1007/s12663-018-1166-4. PMid:31371873.

Tang, J. Y., Huang, H. W., Wang, H. R., Chan, Y. C., Haung, J. W., Shu, C. W., Wu, Y. C., \& Chang, H. W. (2018a). 4beta-Hydroxywithanolide E selectively induces oxidative DNA damage for selective killing of oral cancer cells. Environmental Toxicology, 33(3), 295-304. http:// dx.doi.org/10.1002/tox.22516. PMid:29165875. 
Tang, J. Y., Wu, C. Y., Shu, C. W., Wang, S. C., Chang, M. Y., \& Chang, H. W. (2018b). A novel sulfonyl chromen-4-ones (CHW09) preferentially kills oral cancer cells showing apoptosis, oxidative stress, and DNA damage. Environmental Toxicology, 33(11), 1195-1203. http://dx.doi. org/10.1002/tox.22625. PMid:30256521.

Thorleifsson, G., Walters, G. B., Gudbjartsson, D. F., Steinthorsdottir, V., Sulem, P., Helgadottir, A., Styrkarsdottir, U., Gretarsdottir, S., Thorlacius, S., Jonsdottir, I., Jonsdottir, T., Olafsdottir, E. J., Olafsdottir, G. H., Jonsson, T., Jonsson, F., Borch-Johnsen, K., Hansen, T., Andersen, G., Jorgensen, T., Lauritzen, T., Aben, K. K., Verbeek, A. L., Roeleveld, N., Kampman, E., Yanek, L. R., Becker, L. C., Tryggvadottir, L., Rafnar, T., Becker, D. M., Gulcher, J., Kiemeney, L. A., Pedersen, O., Kong, A., Thorsteinsdottir, U., \& Stefansson, K. (2009). Genome-wide association yields new sequence variants at seven loci that associate with measures of obesity. Nature Genetics, 41(1), 18-24. http://dx.doi.org/10.1038/ ng.274. PMid:19079260.
Wei, Q., Yu, D., Liu, M., Wang, M., Zhao, M., Liu, M., Jia, W., Ma, H., Fang, J., Xu, W., Chen, K., Xu, Z., Wang, J., Tian, L., Yuan, H., Chang, J., Hu, Z., Wei, L., Huang, Y., Han, Y., Liu, J., Han, D., Shen, H., Yang, S., Zheng, H., Ji, Q., Li, D., Tan, W., Wu, C., \& Lin, D. (2014). Genomewide association study identifies three susceptibility loci for laryngeal squamous cell carcinoma in the Chinese population. Nature Genetics, 46(10), 1110-1114. http://dx.doi.org/10.1038/ng.3090. PMid:25194280.

Yoon, H. S., Wen, W., Long, J., Zheng, W., Blot, W. J., \& Cai, Q. (2019). Association of oral health with lung cancer risk in a low-income population of African Americans and European Americans in the Southeastern United States. Lung Cancer (Amsterdam, Netherlands), 127, 90-95. http://dx.doi.org/10.1016/j.lungcan.2018.11.028. PMid:30642558.

Zhao, R., Cheng, G., Wang, B., Qin, C., Liu, Y., Pan, Y., Wang, J., Hua, L., Zhu, W., \& Wang, Z. (2017). BMI and serum lipid parameters predict increasing risk and aggressive prostate cancer in Chinese people. Oncotarget, 8(39), 66051-66060. http://dx.doi.org/10.18632/oncotarget.19790. PMid:29029491. 